\title{
23 レーザー照射光の生体内浸透性に関する試験的検討
}

長澤明範（東海大開発工学部医用生体工学科), 加藤一一 (芝浦工業大工学部通信工学科)

レーザー光の体内浸透性を高め, 治療対象が曝射す る実効光強度を増強することはレーザー治療の治療効 果を向上させる有用な手段である，本研究はレーザー 照射中生体に何らかの負荷操作を加え，それに伴らレ ーザー光組織浸透性に関する試験的実験を行い，血流 動態から検討を加えた。

[実験方法]出力 $\mathrm{mW}$ レベルの $\mathrm{He}: \mathrm{Ne}, \mathrm{Ar}^{+}$, GaAlAs の治療用レーザーを谷々手の皮唐（第一指〜 第二指間母指内転筋部) に照射し，その裏面で厚み約 $10 \mathrm{~mm}$ の生体組織を透過するレーザー光の強度を測 定し，手の血流動態に影響を及ぼすと考えられる三種 の負荷操作 (1)上腕部の加在, (2)手部の加温, (3)手部 の冷却）を加えたときの同部のレーザー透過光強度の 変動を测定した。

[央験結果] (1)加生負荷の場合, 透過光強度は減少し た. (2)加温負荷の場合, 透過光強度は減少する傾向に あった。（3)冷却負荷の場合，透過光強度は顕著に増大
した. 以上の変化は程度の差はあるものの $\mathrm{He}$ : $\mathrm{Ne} レ$

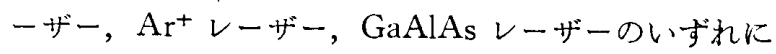
も同様の傾向が認められた。

〔検討】 レーザー血流計 ALF $21 \mathrm{RD}$ (アドバンス) を用いて，本実験結果を血流動態の観点から娭討し た、レーザー光の透過強度には局所を㙺流中の血液量 (MASS) と血流速度 (VELOCITY) の両者が複雑に 関与する.(1)加圧負荷の場合は手の血流は停滞して框 血状態になり，レーザー光の吸収が増大するため，透 過光強度は減少する. (2)加温負荷の場合は MASS の 増加が血流速度の上昇を上回るとき，レーザー光の透 過は低下する。(3)冷却負荷の場合は，血流が低下して 血球成分が減少し貧血状態になるため，透過光強度は 顕著に増大するものと考えられる．以上の変化は血液 による吸収性の大さいレーザーほど顕著に現われるも のと考えられる.

\section{4 レーザー光の生体内浸透性向上に基づく臨床上有用な副操作法について}

長澤明範 (東海大開発工学部医用生体工学科), 加藤一一（芝浦工業大工学部通信工学科）

体表に照射したレーザー光の組織内浸透珄を増強し て体内病巣部の治療效果を可及的に向上寸る方法に関 する基碟的試験的研究の結果, レーザー光の体内浸透 性を左右する最大の因子は局所の血行動態にあること がわかった，この基礎的研究結果，レーザー光の体内 浸透性を向上させるためには局所の血液量を低下させ， 貧血状態をもたらすことが有効であると考えられる。 そこで本研究はレーザー光の組織透過性の向上に関
して, (1)透過光強度, (2)継続時間の点について, 実験 的な檢討を行った，その結果，(1)氷水などでの局所の 冷却（長時間のレーザー照射の場合には, 繰り返し冷 却する方法が有用である)，(2)エピネフリンなどの局 所血管収縮凮の局所注射は, 透過光強度, 持続時間の 両者についてもっとも有用な副操作である, などの結 論を得た。 